\title{
Progress report on a hormonally sensitive neuromuscular system
}

\author{
MARK N. RAND and S. MARC BREEDLOVE \\ University of California, Berkeley, California
}

\begin{abstract}
The bulbocavernosus (BC) muscles are attached to the base of the penis and are active during copulation. In several rodent species, $\mathrm{BC}$ muscles are innervated by motoneurons that form the spinal nucleus of the bulbocavernosus (SNB). The morphology of SNB motoneurons and of the $\mathrm{BC}$ muscles that they innervate, as well as the behavior mediated by those muscles, is sensitive to androgenic hormones both during development and upon maturity. The BC muscles and SNB cells of adult male rats shrink after castration, but the administration of androgens can prevent these changes. Androgens also influence developing SNB cells: at birth, female rats have BC muscles innervated by SNB motoneurons, both of which die soon thereafter. Testicular androgen secretion in male rats prevents the death of these cells, resulting in sexual dimorphism. Perinatal androgens can masculinize females by preventing the death of SNB cells and their targets, but only during that critical period in which they normally die. This androgen-induced sparing of SNB motoneurons is an indirect result of hormone action upon the peripheral target muscle. There is also a sexual dimorphism in the spinal nucleus innervating the $\mathrm{BC}$ in humans.
\end{abstract}

Although there have been many discoveries of sexual dimorphism in the central nervous system (CNS) of various vertebrates, little is known about the relation of such dimorphism to behavior. In the review that follows, we will report investigations of hormones and behavior that emphasize the simplest possible neurobehavioral systema muscle and the neuronal group that controls it-with the hope that we shall at least will be able to relate neural changes in development and adulthood to the behavior of the muscle. The muscles attached to the base of the penis and their motoneurons constitute a neuromuscular system that is found in many mammalian species, is active during reproductive behavior, and, in at least some rodents, is sensitive to gonadal steroid hormones both in development and upon maturity.

The simplicity of this particular system has made it easier to answer five basic questions of behavioral endocrinology. Despite this simplicity, the information still provides only partial answers. However, we feel that the value of this model system lies not in the completeness, but rather in the specificity, of the answers. Whether or not these specific answers will apply to other, more complicated systems, they should at least provide testable hypotheses about steroid action elsewhere, and they should therefore be relevant to psychologists and neuroscientists generally. The five questions are:

(1) What do hormones do to the mature CNS to alter the likelihood of particular behaviors? It is clear that the administration of hormones can transiently activate certain behaviors in vertebrates, but for most of these be-

Correspondence may be addressed to S. Marc Breedlove, Department of Psychology, 3210 Tolman Hall, University of California, Berkeley, CA 94720 . haviors we still do not understand how this activation comes about at the cellular level.

(2) It is also clear that a brief, early exposure of rodents to gonadal steroid hormones can more or less permanently alter the ease with which sexual behaviors are elicited later in life. What are hormones doing to the developing CNS to exert this profound influence on behavior?

(3) When hormones exert such a long-lasting influence on the developing CNS, researchers often speak of a "critical period" during which the treatment is effective. So far, critical periods have been more apparent than understood. What is the cellular basis of such a critical period?

(4) Is, in fact, the CNS the direct target of such early steroid influences, or can the steroid act in the periphery and thereby trigger events that indirectly affect the nervous system?

(5) Finally, what relevance, if any, does animal research such as the above have for humans?

After summarizing some background material, we will review a few recent answers to each of the above questions, with respect to this simple neuromuscular system.

\section{A SIMPLE, HORMONALLY SENSITIVE NEUROBEHAVIORAL SYSTEM}

The striated bulbocavernosus (BC) muscle wraps about the base of the penis in males of-as far as we knowevery mammalian species that has been examined (see Figure 1). In humans, the $\mathrm{BC}$ is active during erection and ejaculation (Karacan, Aslan, \& Hirshkowitz, 1983; Kollberg, Petersen, \& Stener, 1962; Lavoisier, Proulx, Courtois, de Carufel, \& Durand, 1988); in rats, the BC aids the formation and removal of copulatory plugs (Hart \& Melese-d'Hospital, 1983; Sachs, 1982; Wallach \& 
Hart, 1983), activities that are crucial to reproductive success in male rats (Adler, 1969; Chester \& Zucker, 1970; Dewsbury, 1982; Matthews \& Adler, 1978; McClintock, 1984). The $B C$ muscles of rats also mediate certain penile reflexes that can be elicited after midthoracic spinal transections. These spinal reflexes of the penis diminish with castration and are potentiated with androgen treatment (Hart, 1967; Hart \& Leedy, 1985). The rat BC is innervated by motoneurons that occupy a dorsomedial portion of the ventral horn in lumbar segments 5 and 6 , and form the spinal nucleus of the bulbocavernosus (SNB; see Breedlove \& Arnold, 1980; Schrøder, 1980). SNB motoneurons also innervate two other striated perineal muscles: the so-called levator ani (LA) and the external anal sphincter (McKenna \& Nadelhaft, 1986). The LA of rats attaches to the base of the penis and wraps dorsally around the rectum. This muscle, while common in rodents, has no known homologue in humans and might be better thought of as an auxiliary BC (Hayes, 1965). Although the function of the LA in rats is unknown, its exclusive attachment to the penis suggests that it too may serve a sexual function. Thus SNB motoneurons and their target musculature constitute a neuromuscular system that is hormonally sensitive and that mediates sexual behavior. We will refer to these motoneurons and their targets as the SNB system, with the assumption that additional components of the system (peripheral sensory cells, supraspinal controlling elements, spinal internuncial neurons, etc.) will be identified in the future. Some of the neurotransmitters present in this area of the spinal cord have already been identified (Micevych, Coquelin, \& Arnold, 1986; Monaghan \& Breedlove, 1987).

\section{Question 1}

How do hormones in adulthood alter the likelihood of particular behaviors? In the case of the SNB system, we can ask specifically, where and how do androgens act to augment the spinal reflexes of the penis?

First, androgens exert a considerable anabolic influence on the size of the BC muscle itself (Wainman \& Shipounoff, 1941): upon castration the BC and LA shrink to one third their normal size due to a decrease in the size of individual muscle fibers, though testosterone can prevent this shrinkage (Venable, 1966). This large change in muscle size undoubtedly influences the rapidity and/or force with which the muscle responds (Vyskocil \& Gutmann, 1977), and thereby alters behavior. We have recently found that androgens can exert this anabolic effect on BC mass directly: adult male rats were castrated and implanted with silastic capsules containing testosterone over one $\mathrm{BC}$ and a capsule containing the antiandrogen SCH16423 (courtesy of Schering Corporation) over the $\mathrm{BC}$ on the other side. Despite the fact that the $\mathrm{BC}$ is a midline muscle, and that the left and right $\mathrm{BCs}$ are therefore contiguous, after 4 weeks the BC underlying the testosterone capsule was significantly larger than the contralateral muscle adjacent to the antiandrogen (Rand \& Breedlove, 1987). Because the steroid gradient produced at the musculature could not have been preserved at the level of the spinal cord, testosterone must exert a local anabolic influence on the BC (i.e., independent of steroid action in the spinal cord). This direct effect on muscle size is a likely means of potentiating behaviors mediated by the $\mathrm{BC}$.

However, androgens also alter CNS morphology in the SNB system. In Nissl-stained sections, the somata and nuclei of rat SNB motoneurons shrink with castration, but androgen treatment will ameliorate this shrinkage (Breedlove \& Arnold, 1981). The extent of castration-induced changes on SNB size also varies with different strains of laboratory mice (Wee \& Clemens, 1988). In an attempt to relate such changes to naturally occurring biological

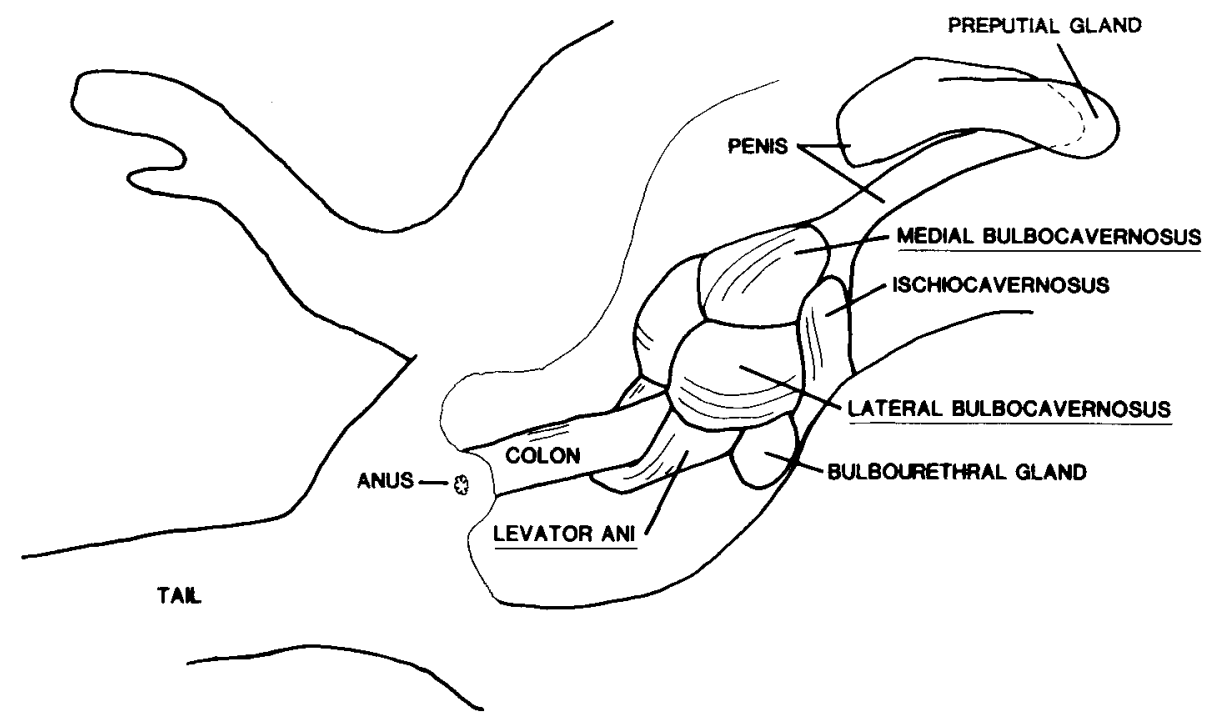

Figure 1. Schematic drawing of perineal region of the male rat. The striated muscles bulbocavernosus (BC) and levator ani (LA) are innervated by the spinal nucleus of the bulbocavernosus (SNB) shown in Figure 3. The $\mathrm{BC}$ aids the deposition and removal of copulatory plugs. 
phenomena, Nancy Forger examined the somata and nuclei of a seasonally breeding rodent, the white-footed mouse, Peromyscus leucopus. The same winter-simulating photoperiodic stimulation that triggers testicular regression and reduced plasma levels of androgens also causes a shrinkage in the somata and nuclei of the SNB in Peromyscus males. If the animals are returned to summerlike photoperiods, testicular function and secretion return and are accompanied by enlargement of SNB somata and nuclei. Influenced by the evidence of DeVoogd and Nottebohm (1981) that songbird neurons extend and retract dendrites seasonally, Forger directly altered androgens of Peromyscus and injected cholera toxin conjugated to horseradish peroxidase (CT-HRP) into the BC. The CTHRP is taken up by motoneurons and distributed within their dendrites, presenting a Golgi-like profile when the HRP is histochemically made visible. The dendritic length of these motoneurons shrank by approximately $20 \%$ after castration, while testosterone treatment prevented this shrinkage (Figure 2; Forger \& Breedlove, 1987b) -an effect that has also been demonstrated in rats (Kurz, Sengelaub, \& Arnold, 1986). Testosterone's effects on adult SNB motoneurons can also be seen at the ultrastructural level, where androgen treatment of castrate males results in larger SNB somata and a greater proportion of somatic membrane receiving synaptic contacts (Leedy, Beattie, \& Bresnahan, 1987; Matsumoto, Micevych, \& Arnold, 1987). These data suggest that the increased size of SNB somata and dendrites indeed reflects additional functional input.

Seasonal changes in neuronal connections and dendritic morphology are therefore not the exclusive bailiwick of songbirds, but can also occur in mammals. Since most temperate-zone mammals are seasonal breeders, annual fluctuations in steroid production may cause more neuronal remodelling than the study of laboratory rodents might suggest.

In summary, androgens have at least two activational influences on the morphology of the mature SNB system: a direct action that increases the mass of the musculature, and an enlargement of motoneuronal somata and dendrites. We do not yet know the primary site of androgen action for the latter effect, but since SNB motoneurons accumulate androgens (Breedlove \& Arnold, 1983a), and testosterone implants in the spinal cord itself augment penile reflexes (Hart \& Haugen, 1968), it is at least possible that androgens act directly upon SNB cells to induce dendritic growth. We must also admit that it has not been proven that any of these morphological changes actually contribute to the androgenic potentiation of penile

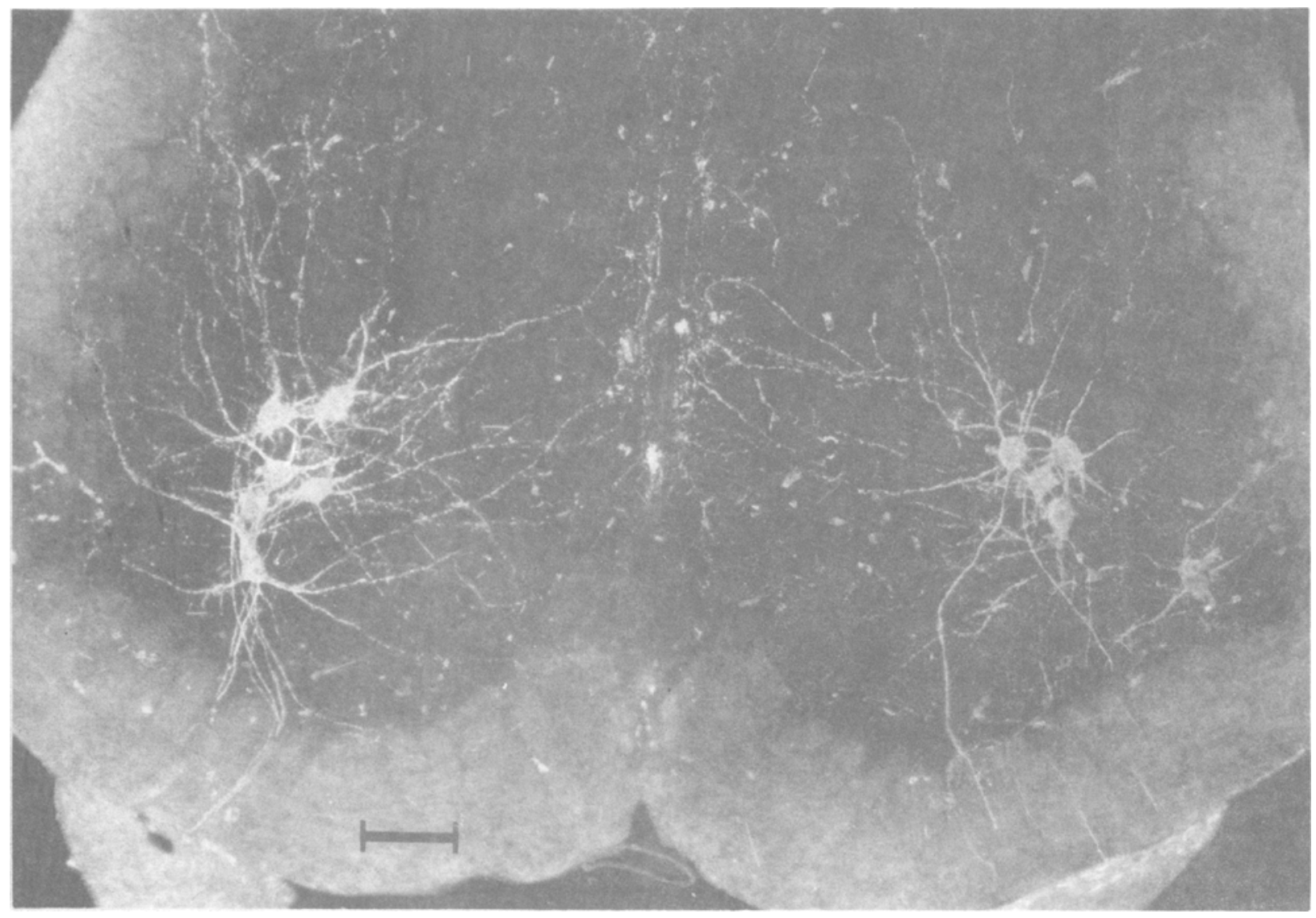

Figure 2. Dark field photomicrograph of SNB motoneurons and their dendritic processes in the spinal cord of a gonadally intact whitefooted mouse, labeled by injecting CT-HRP into the $B C$ muscle. Scale bar $=100 \mu \mathrm{m}$. 
reflexes, but they are reasonable, testable candidates for such action.

\section{Question 2}

How do hormones alter the developing CNS to permanently affect behavior?

So far we have made no mention of the SNB system in females. In fact, the BC muscle is present in adult females of many mammalian species, including dogs, cats, monkeys, and humans. In these species, contraction of the $\mathrm{BC}$ in females constricts the opening of the vagina. In rats and several other rodents, however, there are no $\mathrm{BC}$ or LA muscles in adult females. It is therefore not surprising that adult female rats have far fewer and smaller motoneurons in the SNB region than do males (see Figure 3; Breedlove \& Arnold, 1980). Furthermore, as those familiar with the mammalian sexual differentiation literature would expect, early testicular hormone exposure is responsible for this sexual dimorphism: perinatal androgen deprivation of males results in fewer SNB cells and no BC/LA in adulthood, while perinatal androgen treatment results in both BC/LA and more SNB cells in adult females (Breedlove \& Arnold, 1983b, 1983c; Sachs \& Thomas, 1985).

What is surprising, perhaps, is that female rats normally have BC and LA muscles before birth (Cihak, Gutmann,
\& Hanzlikova, 1970), that these muscles have been contacted by the axons of motoneurons in the SNB (Sengelaub \& Arnold, 1986), and that there is a functional synapse between them on the day before birth (Rand \& Breedlove, 1987). By a few days after birth, the female BC no longer reliably contracts in response to electrical stimulation of appropriate ventral roots, and in the following 1-2 weeks, the muscle disappears (Cihak et al., 1970). Similarly, newborn females have more SNB motoneurons than they will have as adults, and the number of SNB cells declines in the 1st week of life (Breedlove, 1984; Nordeen, Nordeen, Sengelaub, \& Arnold, 1985). Neonatal androgen treatment prevents the decline both of SNB cells and their target musculature (see Figure 4). The death of motoneurons during specific periods of development is a normal part of vertebrate ontogeny (Hamburger \& Oppenheim, 1982). Apparently, the SNB cells of newborn female rats succumb to this ontogenetic death, and androgens prevent their demise in males, resulting in sexual dimorphism.

Thus, in the case of the SNB we conclude that androgens permanently alter CNS morphology by perinatally rescuing motoneurons from cell death. There is evidence that androgens also masculinize birdsong nuclei by means of this same mechanism (Konishi \& Akutagawa, 1985), although the site(s) of steroid action are undetermined.

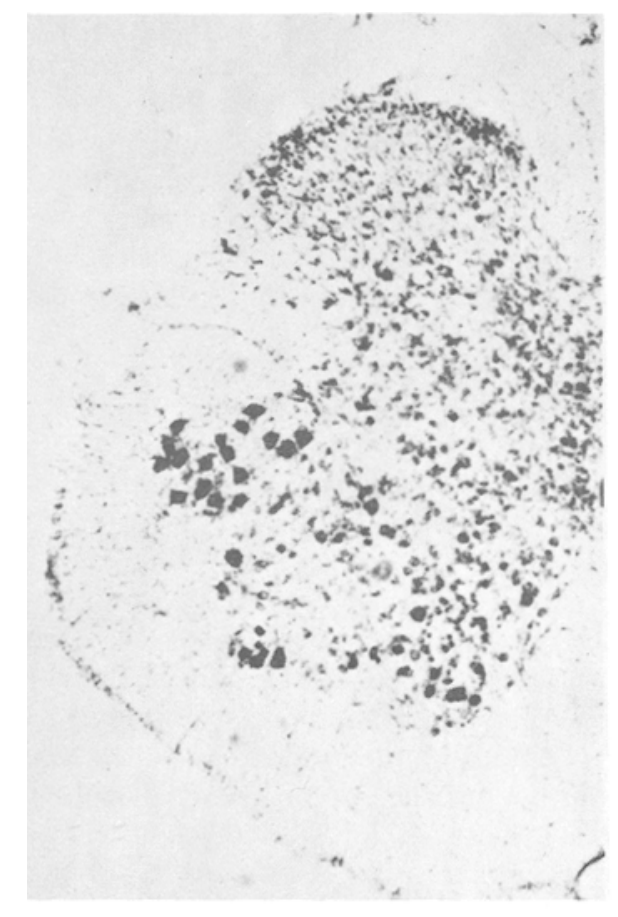

FEMALE

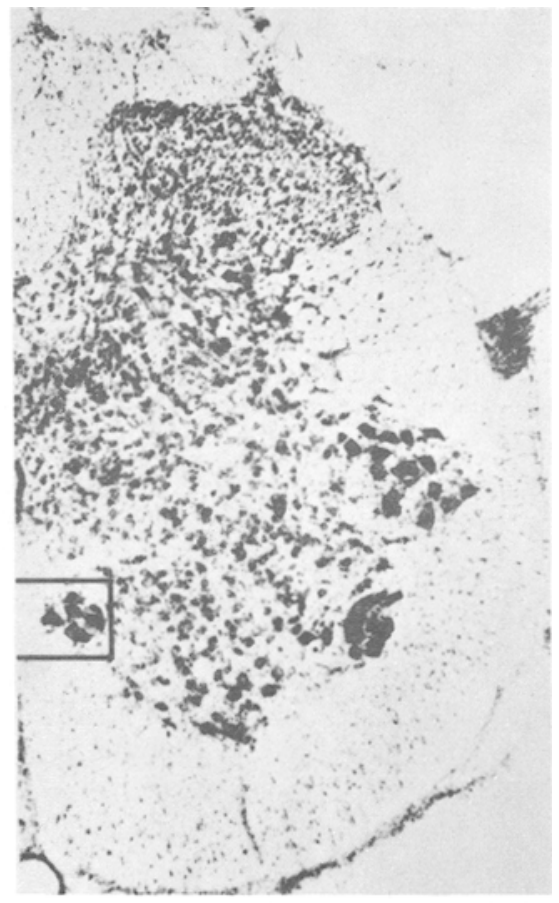

\section{MALE}

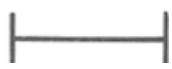

\section{0 um}

Figure 3. Photomicrographs of the fifth lumbar segment of the spinal cord of a female (left) and male rat. The spinal nucleus of the bulbocavernosus (SNB) forms an easily recognized, discrete nucleus in the male only. The brackets indicate the anatomical limits of the SNB in normal males. 


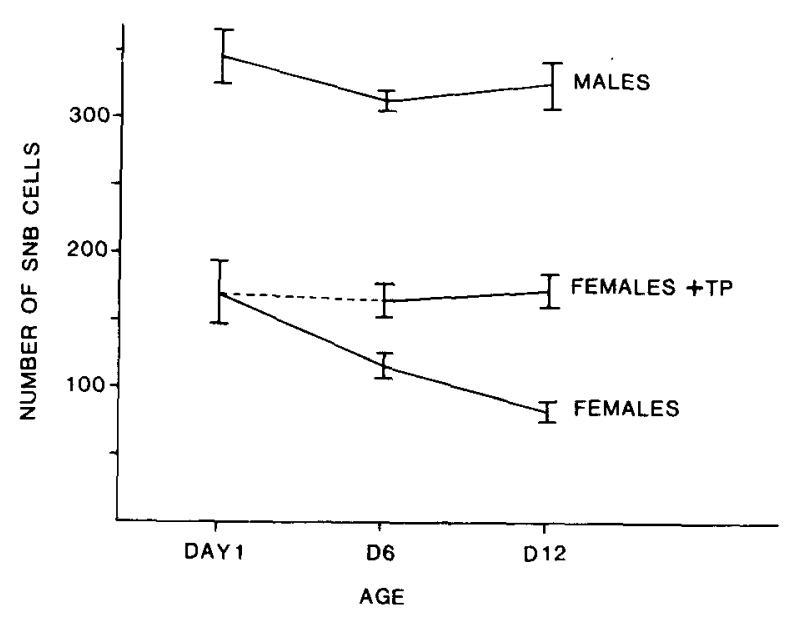

Figure 4. The number of SNB cells in rats during the first weeks of life. At birth, males already have significantly more motoneurons in the SNB region than do females. Although the number of SNB cells does not change thereafter in males, their numbers decline in females. This decline can be halted by treatment with testosterone propionate (TP).

Ecdysteroids can also prevent the death of particular muscles and their motoneurons in insects (Weeks \& Truman, 1986). In this latter case, steroids seem to act upon both motoneurons and muscle. Therefore the attenuation of cell death may be a widespread steroidal mechanism to alter the developing CNS. Steroids can also instigate the death of cells in insects (Truman, 1987), an effect that has not yet been described in vertebrates.

\section{Question 3}

What is the cellular basis of the critical report? Arthur Arnold is fond of phrasing this question thus: "What's critical about the critical period?" The SNB system offers a particularly easy answer to either question: once the motoneurons have died, they can no longer be rescued by androgen, and steroids therefore no longer masculinize the system in terms of SNB number. Having pinpointed this particular cellular mechanism also makes one feel more secure in saying "critical" period rather than the more general and conservative "sensitive" period. Clearly the period of SNB motoneuronal death is a critical time in the life history of these cells, during which steroids can exert long-lasting effects, and after which the cell population remains fixed.

A previous critique of the distinction between the activational and organizational influences of steroid pointed out that most cellular processes could be demonstrated both during development and in maturity (Arnold \& Breedlove, 1985). The attenuation of cell death was the only cellular process that had so far been detected in only one of these modes of action (i.e., instances of cell death seemed to relate only to "organizational" effects). It may be possible that the study of more systems will eventually reveal instances of normal cell death in the mature CNS, and that steroids may occasionally regulate that process. Such a demonstration would further undermine the notion that organizational and activational effects are fundamentally different processes.

The regulation of cell death is not the only influence of androgens, however, because both early and late androgen exposure can increase the size of SNB somata and nuclei in adulthood (Breedlove \& Arnold, 1981, 1983b, $1983 \mathrm{c}$ ). Since the motoneurons (and their targets) are susceptible to such steroidal influences over a long span of time, it seems unlikely that any particular period will prove critical. Rather, it seems more probable that SNB cell morphology (as opposed to survival) is at least partially sensitive for long periods and may be especially sensitive during particular periods. Only a more detailed cellular understanding of which cells are responding to androgens, what that response is, and when cells can show it will allow further pinpointing of putative critical periods for these androgen actions.

\section{Question 4}

Do early steroids shape the developing CNS by interacting with neural tissues directly?

We have already said that fetal female rats make BC/LA muscles and SNB motoneurons, and that they even establish functional connections between the two. We have also said that unless androgens are administered, both the neurons and their targets die. Because both SNB cells and $\mathrm{BC}$ muscles disappear at about the same time, it was not immediately clear whether androgens directly rescued one and thereby indirectly spared the other, or whether androgens interacted with both sets of cells to maintain the system. But over the past few years, Renata Fishman has assembled an increasingly compelling case that androgens act directly upon the target muscles and that the maintenance of SNB motoneurons is a secondary result of that action.

First, the brain was ruled out as a site of androgen's sparing of the SNB system, because transection of the spinal cord between the brain and the SNB in newborn females does not interfere with androgen effects on SNB cell number (Fishman \& Breedlove, 1985). Even when the entire lumbosacral spinal cord is removed from newborn females, the BC/LA muscles are still spared if and only if androgens are provided (Fishman \& Breedlove, 1988). Since neither brain nor spinal connections are a prerequisite for androgen's sparing of the musculature, by elimination one might suspect that the muscle itself was the primary site of androgen action. In fact, a dose of antiandrogen that, when given systemically, is too small to counteract androgen treatment of newborn females is effective when injected directly into the perineum (Fishman \& Breedlove, 1987). This latter result indicates that the musculature itself, or at least something nearby, is the primary target for androgenic sparing of the BC/LA. In support of this view are findings that motoneurons of newborn rats fail to accumulate androgens (Breedlove, 1986), even though the BC/LAs of newborn rats can bind androgens (Fishman, Chism, \& Breedlove, 1988). Fi- 


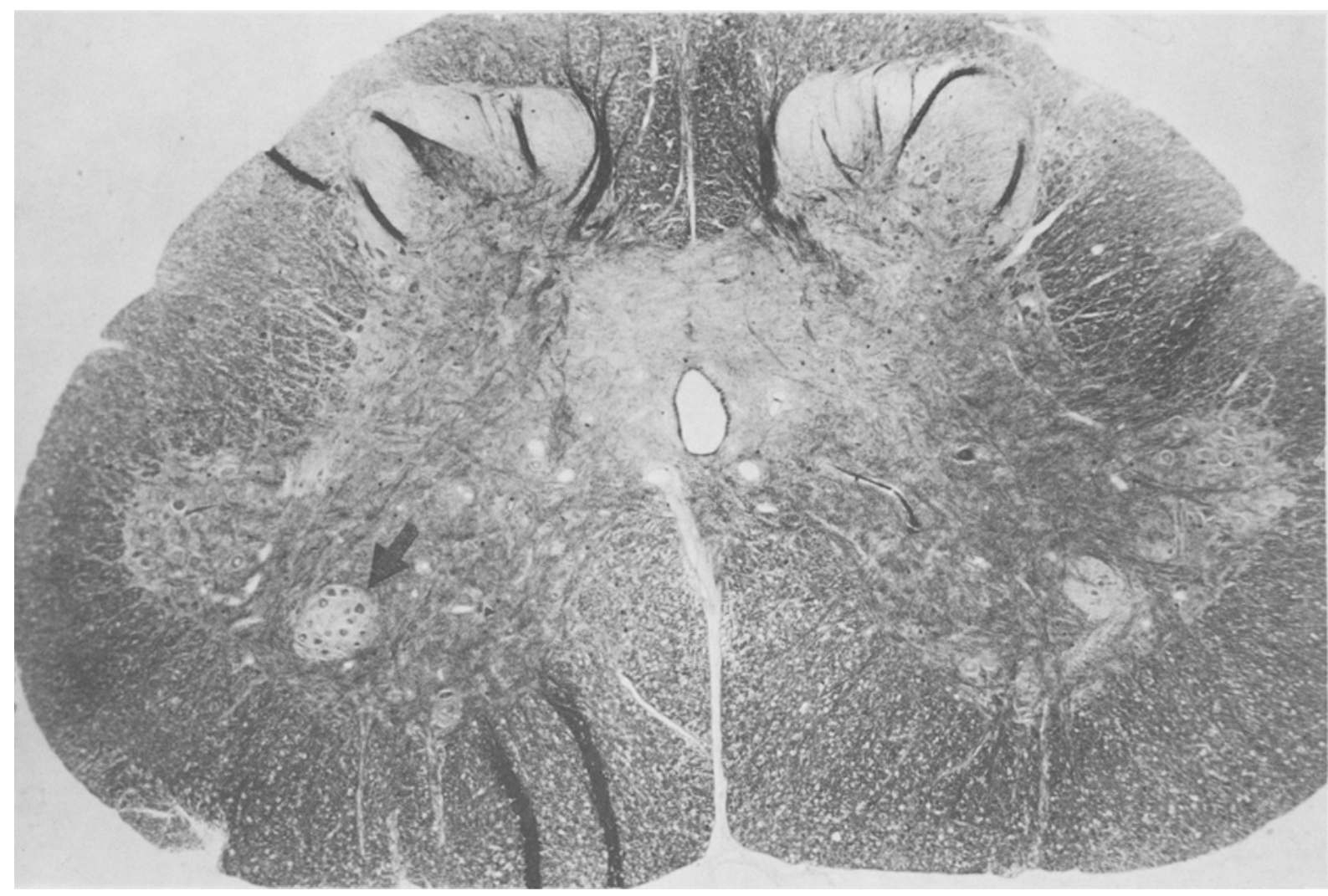

Figure 5. Coronal Klüver-Barrera-stained section through the sacral spinal cord of a female dog exposed to androgen early in development. The arrow points to Onuf's nucleus, which stands out as a pale, oval area devoid of myelinated fibers and innervates the BC and other striated perineal muscles. In both dogs and humans, males have more Onufs motoneurons than do females.

nally, experiments generating mice that are functionally mosaic for the testicular feminization mutation indicate that even such androgen-insensitive SNB cells can be spared by early androgen action (Breedlove, 1985).

So it appears that early androgens masculinize the number of surviving SNB motoneurons, not by interacting with the neurons themselves, but rather as a secondary consequence of sparing their target musculature. The primary site of androgen action is not presently known for any other neural sexual dimorphism, so we cannot gauge how generalizable this indirect mechanism may be. However, the sexual dimorphism of the avian song system includes both the muscles of the vocal organ and their motoneurons, and it is therefore possible that a portion of the masculinization of this system is peripherally driven like that of the SNB.

\section{Question 5}

What relevance, if any, do animal models of neural sexual dimorphism have for humans?

We have already mentioned that the $\mathrm{BC}$ is present in humans of both sexes and that therefore the human homologue of the SNB can be readily recognized as the motoneurons innervating the $\mathrm{BC}$. In fact, the motoneurons of the $\mathrm{BC}$ and other striated perineal muscles are segregated in the upper sacral segments of the spinal cord in the readily identifiable Onuf's nucleus (Onufrowicz, 1899). When Nancy Forger counted the number of motoneurons in Onuf's nucleus in the spinal cords of humans and dogs, she found that males have more of these cells than females do (Figure 5; Forger \& Breedlove, 1986). The sex difference in Onuf's nucleus is not as pronounced in either of these species as the dimorphism of the rat SNB, but that is not surprising, since the BC persists into adulthood in female dogs and humans, and since Onuf's nucleus also innervates non-sexually dimorphic muscles. Is the dimorphism in Onuf's nucleus, like that of the SNB, determined by early androgen action? That notion is directly confirmed in dogs by the finding that prenatal androgenization of females eliminates the adult sex difference in Onuf's nucleus (Forger \& Breedlove, 1986). One cannot manipulate the fetal androgen titers of humans, but a naturally occurring period of motoneuronal death in humans takes place between the 11 th and 26th weeks of gestation (Forger \& Breedlove, 1987a; cf. Figure 6), substantially overlapping the time when fetal males produce testosterone (Diez d'Aux \& Murphy, 1974). Thus it is at least possible that the sexual dimorphism in human Onuf's nucleus is the result of fetal androgens ameliorating ontogenetic motoneuronal 


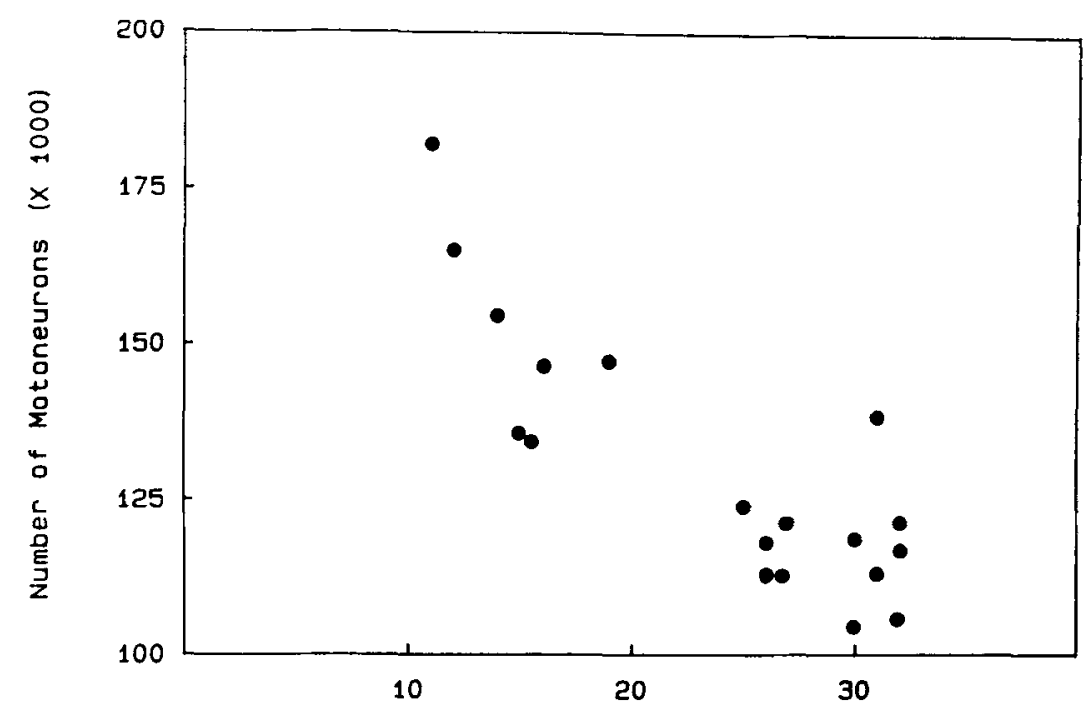

Gestational Age (wks: last menstrual pd.)

Figure 6. Total motoneuron number throughout the ventral spinal cord of 19 human fetuses, ranging in age from 11 to 32 weeks menstrual age, indicating that the period of normal motoneuronal death is over by 26 weeks of age. This time of motoneuronal loss in humans overlaps the period of testicular androgen secretion in males.

death, as is the case for the rat's SNB. If the rat model holds, we should expect that the primary site of steroid action would be the musculature.

\section{CONCLUSION}

We have obviously not yet put together a complete answer to any of the five questions posed here-not even for the simple SNB system, and far less for all the charted sexual dimorphisms in the vertebrate CNS (e.g., see Fishman \& Breedlove's review chapter, 1988). We also suspect that the study of sexual differentiation in the brain, being both figuratively and literally higher, will be much more difficult than our experiments with the spinal cord. Nevertheless, we are encouraged that progress is being made with respect to this simple system, and we hope that the results we find may prove relevant to more complex neurobehavioral systems.

\section{REFERENCES}

ADler, N. T. (1969). Effects of the male's copulatory behavior on successful pregnancy of the female rat. Journal of Comparative Physiology \& Psychology, 69, 613-622.

Arnolo, A. P., Breedlove, S. M. (1985). Organizational and activational effects of sex steroid hormones on vertebrate behavior: A reanalysis. Hormones \& Behavior, 19, 469-498.

BreedLOVe, S. M. (1984). Androgen forms sexually dimorphic spinal nucleus by saving motoneurons from programmed death. Society for Neuroscience Abstracts, $10,927$.

BReEdLOVE, S. M. (1985). Androgen-insensitive SNB motoneurons can be spared by androgen from death during development. Society for Neuroscience Abstracts, 11, 160.

BreedLove, S. M. (1986). Absence of androgen accumulation by motoneurons of neonatal rats. Society for Neuroscience Abstracts, 12 , 1220 .
Breedlove, S. M., \& ARNold, A. P. (1980). Hormone accumulation in a sexually dimorphic motor nucleus in the rat spinal cord. Science, 210, 564-566.

Breedlove, S. M., ARnold, A. P. (1981). Sexually dimorphic motor nucleus in the rat lumbar spinal cord: Response to adult hormone manipulation, absence in androgen-insensitive rats. Brain Research, 225, 297-307.

Breedlove, S. M., \& Arnold, A. P. (1983a). Hormonal control of a developing neuromuscular system: I. Complete demasculinization of the spinal nucleus of the bulbocavernosus in male rats using the anti-androgen, flutamide. Journal of Neuroscience, 3, 417-423.

Breedlove, S. M., ARNold, A. P. (1983b). Hormonal control of a developing neuromuscular system: II. Sensitive periods for the androgen induced masculinization of the rat spinal nucleus of the bulbocavernosus. Journal of Neuroscience, 3, 424-432.

Breedlove, S. M., \& ARnold, A. P. (1983c). Sex differences in the pattern of steroid accumulation by motoneurons of the rat lumbar spinal cord. Journal of Comparative Neurology, 215, 211-216.

Chester, R. V., ZuCKer, I. (1970). Influence of male copulatory behavior on sperm transport, pregnancy, and pseudopregnancy in female rats. Physiology \& Behavior, 5, 35-43.

Cihak, R., Gutmann, E., \& Hanzlikova, V. (1970). Involution and hormone-induced persistence of the muscle sphincter (levator) ani in female rats. Journal of Anatomy, 106, 93-110.

DeVoogn, T., \& Notтевонм, F. (1981). Gonadal hormones induce dendritic growth in the adult avian brain. Science, 214, 202-204.

DEwSBury, D. A. (1982). Dominance rank, copulatory behavior, and differential reproduction. Quarterly Review of Biology, 57, 135-159.

Diez d'AuX, R. C., \& MURPhY, B. E. P. (1974). Androgens in the human fetus. Journal of Steroid Biochemistry, 5, 207-210.

Fishman, R. B., \& BREEDlove, S. M. (1985). The androgenic induction of spinal sexual dimorphism is independent of supraspinal afferents. Developmental Brain Research, 23, 255-258.

Fishman, R. B., \& Breedlove, S. M. (1987). Androgen blockade of bulbocavernosus muscle inhibits testosterone-dependent masculinization of spinal motoneurons in newborn female rats. Society for Neuroscience Abstracts, 13, 1520.

FishmAN, R. B., Breedlove, S. M. (1988). Neonatal androgen maintains sexually dimorphic perineal muscles in the absence of innervation. Muscle \& Nerve, 11, 553-560. 
Fishman, R. B., \& Breedlove, S.M. (1988). Sexual dimorphism in the developing nervous system. In E. Meisami \& P. Timiras (Eds.), Handbook of human growth and developmental biology (Vol. 1). Boca Raton, FL: CRC Press.

Fishman, R. B., Chism, L. M., \& Breedlove, S. M. (1988). Evidence of androgen receptors in neonatal male perineal muscle. Society for Neuroscience Abstracts, 14, 707.

Forger, N. G., \& Breedlove, S. M. (1986). Sexual dimorphism in human and canine spinal cord: Role of early androgen. Proceedings of the National Academy of Sciences, 83, 7527-7531.

Forger, N. G., \& BreEdLove, S. M. (1987a). Motoneuronal death during human fetal development. Joumal of Comparative Neurology, 264, 118-122.

Forger, N. G., \& Breedlove, S. M. (1987b). Seasonal variation in mammalian striated muscle mass and motoneuron morphology. Joumal of Neurobiology, 18, 155-165.

Hamburger, V., \& OPPENHEIM, R. W. (1982). Naturally occurring cell death in vertebrates. Neurosciences Comments, 1, 39-55.

HART, B. L. (1967). Testosterone regulation of sexual reflexes in spinal male rats. Science, 155, 1282-1284.

HART, B. L., \& HAUGEN, C. M. (1968). Activation of sexual reflexes in male rats by spinal implantation of testosterone. Physiology \& Behavior, 3, 735-738.

HART, B. L., \& LEEDY, M. G. (1985). Neurological bases of male sexual behavior: A comparative analysis. In N. T. Adler, D. Pfaff, \& R. W. Goy (Eds.), Handbook of behavioral neurobiology: Vol. 7. Reproduction (pp. 373-390). New York and London: Plenum Press.

Hart, B. L., \& Melese-d'Hospital, Y. (1983). Penile mechanisms and the role of the striated penile muscles in penile reflexes. Physiology \& Behavior, 31, 807-813.

HAYES, K. J. (1965). The so-called "levator ani" of the rat. Acta Endocrinologica, 48, 337-347.

Karacan, I., Aslan, C., \& Hirshkowitz, M. (1983). Erectile mechanisms in man. Science, 220, 1080-1082.

Kollberg, S., Petersen, I., Stener, I. (1962). Preliminary results of an electromyographic study of ejaculation. Acta Chirurgica Scandinavica, 123, 478-483.

Konishi, M., AkUtagawa, E. (1985). Neuronal growth, atrophy and death in a sexually dimorphic song nucleus in the zebra finch brain. Nature, 315, 145-147.

Kurz, E. M., Sengelaub, D. R., \& ARnold, A. P. (1986). Androgens regulate the dendritic length of mammalian motoneurons in adulthood. Science, 232, 395-398.

Lavoisier, P., Proulx, J., Courtois, F., de Carufel, F., \& DURAND, L.-G. (1988). Relationship between perineal muscle contractions, penile tumescence, and penile rigidity during nocturnal erections. Journal of Urology, 139, 176-179.

Leedy, M. G., Beattie, M. S., \& Bresnahan, J. C. (1987). Testosterone-induced plasticity of synaptic inputs to adult mammalian motoneurons. Brain Research, 424, 386-390.

MatThews, M. K., \& AdLER, N. T. (1978). Systematic interrelationship of mating, vaginal plug position, and sperm transport in the rat. Physiology \& Behavior, 20, 303-309.

Matsumoto, A., Micevych, P. E., \& ARnold, A. P. (1987), Androgenic organization of synaptic input to spinal motoneurons in adult rats. Society for Neuroscience Abstracts, 13, 165.

MCClintock, M. K. (1984). Group mating in the domestic rat as a context for sexual selection: Consequences for the analysis of sexual behavior and neuroendocrine responses. Advances in the Study of Behavior, 14, 1-50.

McKenNa, K. E., Nadelhaft, I. (1986). The organization of the pudendal nerve in the male and female rat. Journal of Comparative Neurology, 248, 532-549.

Micevych, P. E., CoQuelin, A., ARnold, A. P. (1986). Immunohistochemical distribution of substance $P$, serotonin, and methionine enkephalin in sexually dimorphic nuclei of the rat lumbar spinal cord. Joumal of Comparative Neurology, 248, 235-244.

Monaghan, E. P., \& Breedlove, S. M. (1987). Evidence for oxytocin innervation of perineal motoneurons in rats. Society for Neuroscience Abstracts, 13, 55.

Nordeen, E. J., Nordeen, K. W., Sengelaub, D. R., \& Arnold, A. P. (1985). Androgens prevent normally occurring cell death in a sexually dimorphic spinal nucleus. Science, 229, 671-673.

ONufrowicz, B. (1899). Notes on the arrangement and function of the cell groups in the sacral region of the spinal cord. Journal of Nervous \& Mental Disease, 26, 498-504.

Rand, M. N., Breedlove, S. M. (1987). Ontogeny of functional innervation of bulbocavernosus muscles in male and female rats. $D e$ velopmental Brain Research, 33, 150-152.

SACHS, B. D. (1982). Role of the rat's striated penile muscles in penile reflexes, copulation and the induction of pregnancy. Jourmal of Reproduction \& Fertility, 66, 433-443.

SaChs, B. D., Thomas, D. A. (1985). Differential effects of perinatal androgen treatment on sexually dimorphic characteristics in rats. Physiology \& Behavior, 34, 735-742.

SCHRODER, H. D. (1980). Organization of the motoneurons innervating the pelvic muscles of the male rat. Joumal of Comparative Neurology, 192, 567-587.

Sengelaub, D. R., \& ARnold, A. P. (1986). Development and loss of early projections in a sexually dimorphic rat spinal nucleus. Jour nal of Neuroscience, 6, 1613-1620.

Truman, J. W. (1987). The insect nervous system as a model system for the study of neuronal death. Current Topics in Developmental Biology, 21, 99-116.

Venable, J. H. (1966). Morphology of the cells of normal, testosterone deprived and testosterone-stimulated levator ani muscles. American Joumal of Anatomy, 119, 271-302.

VySKoCIL, F., \& GUTMANN, F. (1977). Anabolic effect of testosterone on the levator ani muscle of the rat. Pflugers Archiv, 371, 3-8.

Wainman, P., Shipounofy, G. C. (1941). The effects of castration and testosterone propionate on the striated perineal musculature of the rat. Endocrinology, 29, 955-978.

WALLACH, S. J. R., HART, B. D. (1983). The role of the striated penile muscles of the male rat in seminal plug dislodgement and deposition. Physiology \& Behavior, 31, 815-821.

WEE, B. E. F., \& Clemens, L. G. (1987). Characteristics of the spinal nucleus of the bulbocavernosus are influenced by genotype in the house mouse. Brain Research, 424, 305-310.

WeEks, J. C., \& Truman, J. W. (1986). Steroid control of neuron and muscle development during the metamorphosis of an insect. Journal of Neurobiology, 17, 249-267.

(Manuscript received June 2, 1988) 